\title{
The Existence Pattern of Children Literature under the Background of Media Convergence
}

\author{
Mingxiu Ding \\ School of Media and Mathematics \& Physics Sciences in Jilin Engineering Normal University, Jilin \\ Changchun 130052
}

School of Literature in Northeast Normal University, Jilin Changchun 130024

574255187@qq.com

Keywords: Media convergence; Children literature; Obstacles to communication; Existence pattern

\begin{abstract}
The development of media has a great impact on the development of children literature and it provides a broader perspective and space for the development of children literature. The problem to be solved in this paper is how to effectively use the new media and communication means to provide new ideas for the creation and research of children literature and explore new consumer market in the development of it.

China's children literature has gained a great development since the rise of the media industry. There is more research on children literature and more attention has been attracted to children literature in the literary circle. With the convergence of current social media, new era context emerges and communication mode of children literature becomes very important. However, compared with the communication means and modes of other kinds of literature, the communication means of children literature is relatively backward and it causes greater risks to the existence pattern of children literature. In this era with diversified information technology and media means, the network media featuring full interactivity, convergence and individualization, has a certain impact on the original literature circle of children literature and impose a great challenge on the print media. With the development of media technology and convergence of media, they will have a greater impact on the communication and existence pattern of children media. In this context, children literature is facing certain crises and huge potential development opportunities. Therefore, it shall take this opportunity to adjust its communication mode and build new brand development mechanism.
\end{abstract}

\section{Development Way of Children's Literature under the Background of Media Convergence}

Since the end of last century, the research on media has been a hot topic in China's literature filed. The development of media has a huge impact on the development of children literature and provides a broader perspective and space for the development of children literature. The main readers of children literature are children and adolescents, so it has its own literary form uniquely designed for its target readers. Its emergence and development process are different from those of other literatures, so it is a very unique part in the literature field. The research system and assessment system of children literature has been relatively completed. However, in terms of communication mode and means, children literature is still more backward than other literatures, for it only lays emphasis on the analysis of works and the process of new literary theory and media means being introduced into children literature is quite slow. At the same time, children literature is in urgent need for the introduction of new research theory, and new modes and means of communication. [1]

Children literature has always been under the influence of modern media in the development process, so it is necessary to study the relationship between media and children literature. [2] Especially under the current context of media convergence, new elements are generated in the creation and evolution process, providing a good opportunity for the follow-up development of children literature and adding more materials to its communication. With the gradual development of mass media, its market-oriented operation mechanism has become more and more mature and a 
lot of market communication means have emerged in various new media, forming a huge media industry and media culture and penetrate into every aspect of children literature, including the creation, communication, market and other aspects. Today's problem is how to effectively use the new media and communication means to provide new ideas for the creation and research of children literature and explore new consumer market in the development of it. [3] In the development process of traditional children literature, it lays key emphasis on the work itself and authors of children literature have always been the center of research. After the media perspective being introduced to children literature, it should provide new research paradigm through communication theory and means, introduce the elements of media and lay emphasis on the multiple types of communication links of children literature, so as to broaden the research scope of children literature and provide new theoretical support and development direction for the development of children literature.

\section{Influence of Media Convergence on the Development of Media Convergence}

China's children literature has begun to thrive since the end of last century and maintained good development trend in the beginning. However, with the rise of other children works, such as animation and magazines, children literature shows downward trend under the impact of these new forms of media. The sales volume of many typical publications of children literature publications, such as the author's favorite magazine Literature of Children, is not as large as before. Many children and teenagers are attracted by other forms of media, forcing children literature to get trapped in a difficult position without any hope to rise again. However, on the other hand, the convergence of media provides a new form and way for children literature to develop and its existence pattern is possible to become diversified. Specifically, new media provides a better platform for the development of children literature and change the previous single communication channel of it. [4] Children literature not only depends on print media in its communication, but also attracts consumers through audio, video and experiential services. Its target readers can do reading without the restrictions of time and space and read children literature at anytime and anywhere through new media and communicate and interact with other consumers. [5] At the same time, the number of targeted readers of children literature reading circle is also increasing, so it stops being the reading materials designed only for a small group of elites and its aesthetic subject becomes diverse. The resource conversion technology of film, TV, internet and other new media enable the cross-media communication in children literature.

Video media has a positive effect on the development of children literature and they complement each other in the process of development. From the perspective of network media, it differs from video media; network media promotes the diversification in the communication of children literature, but meanwhile it also has a negative impact on the communication of it. First of all, network media is the most convenient and the most rapid carrier and platform and it can transforms paper books into electronic books and communicate them through internet, so as to facilitate the reading and communication of readers. Secondly, network media enable relative freedom and equality, which provides a new way for the communication of children literature. Many writers of children literature can directly write works online and share their works through the network in real time, thus improving the speed and efficiency of children literature communication. At the same time, these writers can also interact with readers effectively and readers can get useful information in the website of writers. However, at the same time, it must be noted that communication through network media is not safe. In case of incompetent network supervision and regulatory loopholes, the fruits of these writers might be grabbed and thieves might spread the works of them arbitrarily, resulting in market confusion and affecting the development of children literature. This is the matter needing special attention in the communication of children literature through internet. 


\section{Analysis of the Current Situation of Children Literature Communication}

Under the background of contemporary media convergence, the communication of children literature is diversified. First of all, the diversification and conversion of media have a negative impact on the development of children literature. Many adult works fill the media market, occupy a lot of market share and take over the market share of children literature. Under the influence of developed video and network media, many children and adolescents begin to be attracted by a variety of cartoons and network fiction. These consumer goods have a strong visual impact and easily attract the attention of children. [6] Under the influence of electronic media, the form of children literature has become diversified, but its specific characteristics increasingly fade away and there is no clear cultural system in it, which falls apart gradually under the background of media convergence. With highly advanced media, children and adolescents have no longer significant passion for literature and show no concern for human society and other problems. At the same time, media convergence has provided powerful resources for and visual impact on children, but it has no big effect on the forming of in-depth thinking pattern for children and, to make matters worse, it is bad for children's imagination. From the perspective of the creation of children literature, the traditional creation form in paper has been transformed and many writers are accustomed to writing children literature on line, so it produces a close link with the market. Once creation of children literature is linked with the market, it will adopt business operation mode and literature will become the consumer goods for the mass and fast-food literature. Moreover, in the era with diversified media, media convergence has also brought instability to children literature. Children literature is in the transition period and it will go through many reforms. In this stage, a variety of content which is not suitable for children is mixed in children literature, especially pornographic and violent content, has a huge negative impact on children's outlook on world and on life and causes children to lose their innocence and passion on reading literature. [7] Many events shows that China's adolescents commit various crimes under the negative influence of media and even younger adolescents tend to commit crimes. This situation is caused by the adverse influence of bad media. Children literature is the food for the mind of children and adolescents, so we must change this situation and help them to maintain innocence and pure spirit. However, the development of children literature has followed the trend of commercialization, so literature has become consumer goods. Meanwhile, children literature has become a victim of popular culture and the unique literary characteristics of children literature gradually fade away under the background of media convergence. [8] Poetry-like description in children literature disappears, few works are created based on children's imagination and innovative thinking and commercial literature fill in children literature. These circumstances must be changed. We should restore the creative spirit and artistic benchmark, as well as the unique spiritual characteristics of children literature, so as to avoid the fall of this literature field.

\section{The Ways to Establish New Mechanism of Communication and Development for Children Literature}

Firstly, it is necessary to establish a new type of operation mechanism for children literature in combination with media communication mode. With the development and convergence of various media, children literature has a broad market, adopts industrialization development path channel and has a diversified development mechanism, which affect the creation and publication chain of children literature. Therefore, industrialization is a way that children literature must take under the background of current media convergence, for it has a strong market advantage and provides a promising market prospect for children literature. Nowadays, in order to get rid of the difficult position in development, children literature shall no longer take the single product line. Instead, the relevant people involved shall explore the market with three-dimensional creation and marketing channels, reform previous paper-based communication means, and introduce children literature to larger consumer groups through diversified video and network media. Meanwhile, it shall be noted that children literature includes not only paper-based publications, but also other forms of works, such as cartoons, which can attract targeted readers and improve their reading experience. 
Therefore, the operation mechanism of children literature shall be reformed depending on advantages of media convergence and three-dimensional mode of communication shall also be adopted to attract readers, so as to provide a new development path for children literature

Secondly, build proprietary brands for children literature and improve its influence and attractiveness. In the publishing practice of children literature, brand advantage of children literature has not been explored well. The previous paper-based communication way attracts limited target readers and provides bad reading experience, so it is difficult to form relatively strong brand advantages. Under the background of media convergence, diversified media communication ways provide a new platform for the publication of children literature. Since the market of children literature is highly competitive, only strong brands can succeed in it. Therefore, enhancing brand effect is an important measure for various children literature publishing houses to take. [9] Many publishing houses enhance their own advantage advantages depending on the influence of famous writers through entering into a long-term contract with these writers. A typical example is that Shanghai literature and Art Publishing House establishes a long-term cooperation with a celebrity named Yi Zhongtian, who earns his fame in a TV show named "Lecture Room" in China Central Television (CCTV). This publishing house exploits market and builds its own brand culture depending on the brand influence of Yi Zhongtian. It shows that they complement each other with their own advantages. The famous author and the well-known publishing house cooperate with each other to exploit the literature market. In order to make further progress, this experience shall be adopted in children literature. [10] Firstly, relevant publishing houses in the field of children literature shall deal with relevant copyright matter, integrate various advantages in publication, build brands in children literature depending on new media and do image design and propaganda work in this process. Secondly, cooperation with private publishing enterprises shall be strengthened. At present, China's private publishing enterprises show a rapid development and have considerable market potential. This kind of advantages of private enterprises shall be used to improve the brand awareness of children literature works and the influence of the private publishing enterprises in the market through cooperation, so as to get win-win situation. In addition, the creation modes in children literature should be vigorously innovated and reformed to create new literary genres and introduce new vitality to the development of children literature.

Thirdly, innovate new marketing mechanisms and make organic combination with media communication. First of all, relevant operators shall have a complete understanding of the market operation mechanism of children literature and its market potential. For the readers of children literature, the arrangement and depth of ideas in a work determine its attractiveness. At the same time, market scope and breadth are the basis of literary creation. Therefore, children literature works shall fully meet the needs of children and adolescents, dig up points of interest, reflect them in various literary forms and make in-depth research in combination with popular hot topics, so as to improve the adaptability of children literature to the market and improve its influence on literature market. Secondly, perfect promotion strategies shall be developed for children literature. Since the targeted consumers of children literature are children and adolescents, who mainly choose literary works under the guidance and recommendation of their parents and other relevant adults, appropriate marketing strategies shall be adopted. The promotion of children literature is quite different from that adopted in other literature types, for it is necessary for children literature to cater to both its original targeted readers and other relevant consumer groups. Specifically speaking, in order to gain larger market share, children literature shall not only take into account the cognitive level and reading experience of children and adolescents, but also cater to the consumption desires and ability of parents, so as to achieve good results from its market expansion strategies. At the same time, children literature has regional differences and each regional children literature market varies in market direction and potential, so relevant operators shall deal with different markets in different ways. The common error for many publishing houses is that they make overall marketing strategies based on big national picture. They actually make a mistake in obtaining the market share by overlooking the influence of the regional features of children literature on the market, resulting in dull sale of books and bad market prospect. Therefore, relevant publishing houses shall make full 
research on the actual demand of local book markets, do book marketing with clear direction and targeted readers, exploit national market after laying solid foundation on every local markets and carry out market expansion strategies for children literature step by step.

\section{Conclusion}

This paper starts with depiction of the development of children literature under the background of media convergence, then describes the impact of media convergence on the development of children literature, analyzes the current situation of children literature communication and proposes methods to build new communication and development mechanism for children literature. Under the background of contemporary media convergence, children literature has diversified communication ways. The diversification and conversion of media have a negative impact on the development of children literature. In the era with diversified media, media convergence has also brought instability to children literature. Therefore, we should establish new operation mechanism for children literature in combination with various media communication forms and build proprietary brands for children literature works to improve their influence and attractiveness; meanwhile, we should create new marketing mechanisms, which shall be in organic combination with media communication.

\section{References}

[1] L.N. Hu: Television and Film Adaptation and Cross-Media Communication of Children Literature, Vol. 2011 (04), p.81-82. (In Chinese)

[2] X.D. Tan: Reconstruction of Literature Field - Media and Literature in Modern Situation (Dunhuang Literature and Art Publishing House, China 2010). (In Chinese)

[3] Y. Sun: Analysis of Literature Development Direction in the Era of New Media, Vol. 2011 (06), p.98-99. (In Chinese)

[4] Q. Wang: Attribution Research on Obstacles to Communication of Children Media in the Context of Mass Media (Ph.D., Shandong Normal University, China, 2012), p. 209. (In Chinese)

[5] Q. Wang: Three Major Obstacles in the Communication of Children Literature and Countermeasures, Vol. 2012 (02), p.88-91. (In Chinese)

[6] W. Bu: The Influence of Mass Media on Children (Xinhua Publishing House, China, 2002). (In Chinese)

[7] [United States] Neil Bozmann: Disappearance of Childhood (Translated by Wu Yanting) (Guangxi Normal University Press, China, 2011). (In Chinese)

[8] G.Q. Zhou and Z. Mo: Breakthrough of Children Literature in the Electronic Media Era, Vol. 2011 (09), p.25-28. (In Chinese)

[9] X.P. Cui: Children Literature from the Perspective of Publication and Communication (Chinese Social Sciences Press, China, 2014). (In Chinese)

[10]C.Z. Liu: Visualization and Cannibalization: Excessive Aesthetic Tendency of Children Literature in the New Media Era, Vol. 2011 (06), p.49-51. (In Chinese) 